\title{
Remote Prophylaxis of Social and Educational Adaptation of University International Entrants in Total Pandemic
}

\section{Profilaxis remota de la adaptación social y educativa de ingresantes universitarios internacionales en pandemia total}

\author{
Firaya F. Bulatova \\ Master Student of the Institute of Psychology and Education, Kazan (Volga region) Federal University, \\ Kazan, Russia. \\ ORCID ID: 0000-00023680-847X.
}

Natalia S. Sakharova

Doctor of Education, Professor, Head of the Department of Foreign Languages, Orenburg State University, Orenburg, Russia.

ORCID ID: 0000-0002-1770-275X

Vitaly V. Tomin

PhD in Education, Associate Professor of the Department of Foreign Languages, Orenburg State University, Orenburg, Russia.

ORCID ID: 0000-0002-7679-843X

Irina R. Pozdnyakova

$\mathrm{PhD}$ in Education, $\mathrm{PhD}$ in Education, Associate Professor of the Department of Psychology and Education, Gzhel State University, Elektroizolyator, Russia. ORCID ID: 0000-0003-4796-3827

\section{Rashad A. Kurbanov}

Doctor of Law, Professor, Head of the Department of Legal Basis of the Economic Activity, Institute of Legislation and Comparative Law under the Government of the Russian Federation, Moscow, Russia. ORCID ID: 0000-0001-7900-1302

Asiya M. Belyalova

Acting Head of the International Cooperation Department, Institute of Legislation and Comparative Law under the Government of the Russian Federation, Moscow, Russia. ORCID ID: 0000-0002-8916-4559

\section{Maksim A. Suchkov}

$\mathrm{PhD}$ in Economics, Associate Professor of the Department of Management and Business Technologies, Kazan National Research Technological University, Kazan, Russia. ORCID ID: 0000-0003-3551-7256

Received 09-08-20 Revised 10-10-20

* Correspondence

Email: firaya.bulatova@bk.ru
Accepted 12-12-20 On line 03-12-21

\section{Citation:}

Firaya F. Bulatova, Natalia S. Sakharova, Vitaly V. Tomin, Irina R. Pozdnyakova, Rashad A. Kurbanov, Asiya M. Belyalova, Maksim A. Suchkov. (2021). Remote Prophylaxis of Social and Educational Adaptation of University International Entrants in Total Pandemic. Propósitos y Representaciones, 9 (SPE3), e1131. Doi: http://dx.doi.org/10.20511/pyr2021.v9nSPE3.1131 


\begin{abstract}
The relevance of the study is due to the trends of the global pandemic, which provoked an extremal transition of all areas of higher education to distance learning, as the only possible way to work with domestic and international entrants and students. In addition, the trends of the pandemic in the current educational environment also determine the special need to develop remote mechanisms for a prophylaxis approach to solving the problems of social and educational adaptation of international entrants - future University students. In this regard, this article is aimed at identifying the features of remote prophylaxis of social and educational adaptation of entrants. The article reveals the transformation of social and educational adaptation of international entrants in the global pandemic; defines the structure and content of remote prophylaxis of social and educational adaptation of international University entrants in the global pandemic. Based on the results of the research, the authors of the article substantiate the prophylaxis model of the educational and software complex for remote prophylaxis of social and educational adaptation of University international entrants. The effectiveness of the model is proved by the results of its use in the process of remote social and educational adaptation of University international entrants in the context of a global pandemic. The materials of the article have practical application and can be useful in the development and implementation of various methods and practices of social and educational adaptation of international entrants - future University students in the context of a global pandemic. It is recommended for University teachers and students, methodologists, curators, Tutors.
\end{abstract}

Keywords: global pandemic, remote educational process, international entrant, target groups of entrants, social and educational adaptation of international entrant, prophylaxis of remote adaptation of entrant, recruitment process, preventive model, educational and software package.

\title{
Resumen
}

La relevancia del estudio se debe a las tendencias de la pandemia global, que provocó una transición extrema de todas las áreas de la educación superior a la educación a distancia, como la única forma posible de trabajar con estudiantes y estudiantes nacionales e internacionales. Además, las tendencias de la pandemia en el entorno educativo actual también determinan la especial necesidad de desarrollar mecanismos remotos para un enfoque de profilaxis para resolver los problemas de adaptación social y educativa de los ingresantes internacionales - futuros estudiantes universitarios. En este sentido, este artículo tiene como objetivo identificar las características de la profilaxis remota de la adaptación social y educativa de los ingresantes. El artículo revela la transformación de la adaptación social y educativa de los participantes internacionales en la pandemia global; define la estructura y el contenido de la profilaxis remota de la adaptación social y educativa de los recién ingresados a universidades internacionales en la pandemia global. Con base en los resultados de la investigación, los autores del artículo fundamentan el modelo de profilaxis del complejo educativo y software para la profilaxis remota de la adaptación social y educativa de los ingresantes internacionales a la Universidad. La efectividad del modelo está probada por los resultados de su uso en el proceso de adaptación social y educativa remota de los ingresantes internacionales de la Universidad en el contexto de una pandemia global. Los materiales del artículo tienen aplicación práctica y pueden ser útiles en el desarrollo e implementación de diversos métodos y prácticas de adaptación social y educativa de los participantes internacionales - futuros estudiantes universitarios en el contexto de una pandemia global. Recomendado para profesores y estudiantes universitarios, metodólogos, comisarios, tutores.

Palabras clave: pandemia global, proceso educativo remoto, ingresante internacional, grupos objetivo de ingresantes, adaptación social y educativa del ingresante internacional, profilaxis de la adaptación remota del ingresante, proceso de reclutamiento, modelo preventivo, paquete educativo y de software. 


\section{Introduction}

The problem of primary importance for the world's higher education systems today is to overcome the negative impact of the global pandemic on the life of educational institutions, to attract a new generation of creative youth to study at universities, including from other countries (Vashurina, Vershinina \& Gazieva, 2016; Mironova et al., 2017; Cherdymova et al., 2018; Razumovskaya et al., 2018; Pushkarev et al., 2019; Bayanova et al., 2019a; Bayanova et al., 2019b; Gafurov et al., 2020; Salnikova, 2020; Shtykhno, Konstantinova \& Gagiev, 2020). There is a tradition in the world experience of higher education to evaluate the popularity and success of a University in the educational services market by the number of international entrants and students (Report on international migration of the UN population Division, 2012). For many foreign universities, an increase in the number of international students increases the level of financial situation due to budget revenues from students' expenses for accommodation, transport, entertainment, and medical care (Salnikova, 2020). For top leaders of the world rankings (Harvard, Stanford, Oxford universities), international entrants are a source of replenishment of the student body with gifted young people from all over the world. Most universities in the world community consider the expansion of admission of foreign entrats as an important factor in the internationalization of education, creating a prototype of an international and intercultural environment in their own educational institution that transforms all areas of activity (Valers, 2018; Kvon et al., 2019; Malikov, Potapova \& Gavrilyuk, 2020). There is another area that is extremely important for the prestige of a modern University in the global educational market - membership in the list of 100 branded universities in the world. It is established that the presence of the University in this list confirms its international reputation and authority in academic circles and among employers (The 100 Most International Universities in the world, 2015/2018). The stability of the presented trends in the practical activities of modern universities in the context of the pandemic expands the distancelearning format, which requires the intensification of new approaches to the social and educational adaptation of international entrants (Marinoni \& Hilligye van't, 2010; Faleeva et al., 2017; Kvon et al., 2019; Aleshkovsky, Gasparishvili \& Krukhmaleva, 2020; Bayanova et al., 2020; Salnikova, 2020). In this regard, the article substantiates the theoretical and methodical approach to the development of a preventive model of the educational and software complex for remote prophylaxis of social and educational adaptation of University international entrants in the context of a global pandemic as an independent scientific direction. Pedagogical monitoring is used as the leading research method to implement the theoretical and practical bases for the development of this model. The article reveals the transformations of social and educational adaptation of international entrants in the context of a global pandemic; defines the structure and content of remote prophylaxis of social and educational adaptation of University international entrants. Based on the results of the research, the authors of the article substantiate the preventive model of the educational and software complex for remote prophylaxis of social and educational adaptation of University international entrants. The effectiveness of the model is confirmed by the results of its implementation in the process of remote social and educational adaptation of international entrants in the context of a global pandemic. The materials of the article are focused on practical application and assistance to University teachers and students, methodologists, curators, Tutors in the development and implementation of various methods and practices of social and educational adaptation of international entrants.

\section{Literature Review}

The problem of adaptation of an international entrant in the scientific discourse was identified in a significant number of works before the pandemic period, which are of scientific and practical interest for modern researchers (Gladush, Trofimova \& Filippov, 2008; Domorovskaya, 2007; Drozhzhina, 2013; Becker \& Kolster, 2012; Ivanova, 2001; Krivtsova, 2011; Natolochnaya, Kryukova \& Buslaev, 2016; Kutuev et al., 2017). Of particular interest in the aspect of the problem under study is the collective monograph of employees of Kazan Federal University, dedicated to the issues of attracting foreign citizens to study in regional universities (Vashurina, Vershinina \& Gazieva, 2016; Ezhov et al., 2019; Galiskan et al., 2019). This paper presents the results of an analysis of global trends, national policies and practices of leading universities in the field of export of educational services, summarizes domestic and foreign experience in attracting international entrants to 
University, and develops a comprehensive technique for creating and implementing a system for attracting international entrants at Kazan Federal University. Significant attention is paid to the issues of international entrants' adaptation - University future students before the pandemic period in the content of policy documents, the core idea of which is to expand modern resources for attracting international students to study at universities in the country and promote higher education as a national priority on this basis (the Concept of the state migration policy of the Russian Federation for the period up to 2025, 2012; the Concept of promoting Russian education on the basis of Russian Collaboration representative offices abroad, 2014; Concept of the state policy of the Russian Federation in the field of training national personnel for foreign countries in Russian educational institutions, 2016). Extraordinary approaches to remote training of University international entrants using digital platforms for internationalization of higher education are revealed in the analytical report of leading Russian universities (lessons of the Stress test: universities in the context of the pandemic and after it, 2020). The conceptual approaches to internationalization and digitalization of higher education presented in the report can be used as theoretically and practically significant areas of modern research (Rudenko et al., 2018). The results of this study show that despite the multi-faceted active interest of specialists in the problem of adaptation of an international entrant in the digital educational environment of a University, a holistic scientifically based approach to its remote implementation in the context of a global pandemic is not yet observed in the presented works. To date, there is a significant desynchronization of theoretical and methodical problems, which does not contribute to their productive solution. Therefore, the study of remote prophylaxis of social and educational adaptation of university international entrant seems justified and timely for educational theory and practice in the context of a global pandemic.

\section{Results and Discussion}

\section{Transformations of Social and Educational Adaptation of University International Entrants in the Context of a Global Pandemic}

In the course of the study, the priorities of strategies of modern educational systems that are important for solving the problems of this study are identified. The strategies are determined by the processes of internationalization of higher education and focus universities on expanding the formats of international academic mobility, on leadership among universities, on academic cooperation and networking with new promising partners. This format is expanded by the risks of a global pandemic, which have made the higher education system face the need to switch to implementing digital strategies for distance internationalization. In the course of monitoring the development of social and educational adaptation of University international entrants in the face of global pandemic risks, the structure and content of priority transformations of this process due to the transition to a remote format of interaction with international entrants were established:

1. Changing the structure of admission of international entrants to higher education institutions based on the classification of target groups recommended for use by international educational and methodical registers (The 100 Most International Universities in the world, 2015/2018). In accordance with the contents of the registers all the international entrants taking into account external and internal factors prescribed by instructional registers to use when dealing with entrants (number of entrants, the structure of the population in countries of arrival, the ratings of General education, by level of language proficiency, based on the choice of University) are distributed to the target groups in areas of training (bachelor, specialist, master). Currently, these target groups determine the direction of theoretical and methodical approaches to the design and implementation of adaptation models for University international entrants (Vashurina, Vershinina \& Gazieva, 2016; Orekhovskaya et al., 2019; Kargapoltseva et al., 2019; Shtykhno, Konstantinova $\&$ Gagiev, 2020).

2. Expanding the boundaries of academic mobility of higher education institutions that intensify interest in it from entrants: the popularity of training curricula and accommodation; high training rating, tuition fees, scholarship programs for international entrants, employment opportunities during training, and additional financial assistance. Attractive indicators of mobility 
in the presented list are the quality of digital resources in the equipment of classrooms, libraries, information centers, and the availability of University campuses, the ability to perform educational tasks on campus during and after classes. Cooperation with recruitment companies and the expansion of services for the adaptation of international entrants, the creation of associations of entrants and branches of the University abroad are of well-deserved interest.

3. Students health and lives safety system in the context of global pandemic and risks of its spreading in the environment: characteristics of the pandemic situation in the world; the prevalence of the pandemic in the University, the city, in the district of residence, on campus; measures to combat the pandemic from the power structures, population, volunteers, NGOs; the presence of systemic anti-epidemic measures against the virus; relationships between people during a pandemic: mutual assistance, attentive attitude to each other, selflessness, efficiency, organization, cohesion, lack of chaos; confidence in the suspension of the pandemic; own participation in the response to the pandemic.

\section{Structure and Content of Remote Prophylaxis of Social and Educational Adaptation of University International Entrants in the Context of a Global Pandemic}

The discursive contents of the remote prophylaxis of social and academic adaptation of international entrant in the global pandemic is determined by the assistance to its development in distant form of the University educational environment and by the prevention of potential difficulties in social and learning adaptation, including prevention risks of a pandemic. The study found that the practical meaning of remote prophylaxis of social and educational adaptation of international entrants in the context of a global pandemic is to create a safe and comfortable environment for students that meets competitive programs and standards of educational services provided by the University. As a rule, universities evaluate the current situation to prevent possible adaptation difficulties of international entrants and develop recommendations for their prevention based on quantitative and qualitative benchmarking criteria used as indicators of the process success of the University internationalization in international and national ratings, monitorings, self-surveys, analytical reports (Vashurina, Vershinina \& Gazieva, 2016; Kvon et al., 2019; Bayanova et al., 2019b; Bubnova et al., 2018; Marinoni \& Hilligye van't, 2020). Based on benchmarking indicators, in this study, barriers are established to counter social and academic adaptation of international entrants in remote educational space of the University and the nature of their influence on the adaptive capabilities of the individual is determined. These are barriers of a physiological, psychological, emotional, linguistic, motivational, and communication nature, reinforced by the extraordinary factors of the pandemic. It is proved that the set of established barriers remains relevant for entrants who are at a remote distance from the University, even in a home environment. It is established that remote prophylaxis of emerging barriers to social and educational adaptation of University international entrant involves the use of preventive methods of work of teachers and specialists interacting on the principle of an adaptation chain: curators - teachers - up bringers in campus - Tutors - electronic deans' offices for working with international entrants - primary groups of entrants on campus, in the study group self - government and volunteer activities of the preparatory Department - fellowships-public organizations of the University, city, basic industry. The study proved the effectiveness of interaction between the structures of the adaptation chain with the help of electronic means that are in the resource support of the University. The main types of remote prophylaxis of social and educational adaptation of international entrants in the practical activities of universities in the current conditions are recognized:

1) Special master classes focused on the formation of competencies for remote overcoming of barriers to social and educational adaptation by international entrants in the context of a global pandemic;

2) remote programs for the formation of temporary primary groups of entrants, focused on the implementation of factors of student cohesion based on creative interests, abilities, talents, participation in the volunteer, sports, and cultural life of the University; 
3) Activities of teachers-educators on campus. These specialists provide the necessary consulting, preventive and ongoing assistance in organizing the life of an international entrant on campus, using modern electronic means of communication;

4) Service of Educational and Social Tutors. Tutors usually carry out their work in no more than one or two areas (specialties) and supervise applicants from the time of admission to the University until graduation.

\section{Preventive Model of the Educational and Software Complex for Remote Prophylaxis of Social and Educational Adaptation of University International Entrants}

In the course of the monitoring study, the authors of the article implemented a preventive model of the educational software package aimed at assisting international entrants in remote prophylaxis of social and educational adaptation in the extraordinary conditions of the global pandemic.

Structure and content of the model:

The first level of the model. Educational strategies of the structures responsible for remote prevention of social and educational adaptation of international entrants. The strategies are determined by the processes of internationalization of higher education and focus universities on expanding the formats of international academic mobility, on leadership among universities, on academic cooperation and networking with new promising partners. This format is complicated by the risks of a global pandemic, which has made the higher education system face the need to switch to implementing digital strategies for distance internationalization.

Second level of the model. Educational materials on the organization and conduct of entrance tests, selection and enrollment international entrants. Expert procedures are carried out using all available electronic means: e-mail, website, University pages in social networks, mobile applications, telephone, Fax, Skype, personal requests, automatic notification system. Due to the risks of a pandemic, these procedures are carried out using digital means remotely on the territory of consulates, universities and their branches, joint educational centers, if any; during subject and language Olympiads and exams at the regional and international level, followed by face-to-face interviews;

The third level of the model. Monitoring, evaluation, activities of the admission company, analysis of the objective state of Affairs for the admission of international entrants; determining the directions of social and educational adaptation of international entrants and the range of problems arising in connection with these areas in the context of the pandemic;

The fourth level of the model. Experimental materials of blitz interviews with international entrants. They are focused on determining: the motives for choosing a University by entrants as a place of study; sources of information that applicants used when choosing a University; the quality of University services, wishes for their improvement; remote difficulties of social and educational adaptation; the overall level of satisfaction of an international entrant with the choice of a University;

The fifth level of the model. Propaedeutic master class adaptation Lessons - a remote Navigator in the field of social and educational adaptation of University international entrants. It is developed in the entrants' native languages. It is subject to mandatory mailing by the University to each entrant. The contents of the master class is based on generalized information from previous sections of the training software system and introduces international entrants to the field of information of reference, legal, cross-cultural, historical, cultural, linguistic nature, necessary for a remote acquaintance with the peculiarities of social and learning adaptation in educational space of the University, city, country for the coming period of training. The organizational and methodical solution of the master class tasks depends on the creative initiative of performers, digital resources for implementation, and the level of spread of the global pandemic, which in the current conditions preserves the stable extraordinary nature of countering the processes of social and educational adaptation of University international entrants. 


\section{Conclusion}

The study confirms the theoretical and practical significance of the problem of remote prevention of international entrants' social and educational adaptation as an independent scientific direction determined by the dangerous conditions of the global pandemic. Based on the results of monitoring the processes of internationalization in the practice of higher education institutions in the context of a global pandemic, priority strategies have been established that permanently expand the distancelearning format, which requires the intensification of new approaches to the social and educational adaptation of international entrants. In this regard, the article substantiates a theoretical and methodical approach to remote prophylaxis of social and educational adaptation of University international entrants in the context of a global pandemic as an independent scientific direction. The article reveals:

1) Transformations of social and educational adaptation of international entrants in the context of a global pandemic;

2) The structure and content of remote prophylaxis of social and educational adaptation of University international entrants are defined;

3) Based on the results of the research, the authors of the article substantiate the preventive model of the educational and software complex for remote prophylaxis of social and educational adaptation of University international entrants. The effectiveness of the model is proved by the results of its use in the process of remote social and educational adaptation of University international entrants in the context of a global pandemic. This problem as an independent scientific direction does not exhaust itself by solving the tasks set. Special attention should be paid to projects that create joint educational programs and two-degree programs with foreign partners.

\section{References}

Aleshkovsky, I.A., Gasparishvili, A.T., Krukhmaleva, O.V. (2020). Russian University students about distance learning: assessment and opportunities. Higher education in Russia, 10, 7691.

Bayanova, A.R., Sabaeva, E.K., Sakhipova, Z.M., Zatsepina, M.B., Tararina, L.I., Votinov, A.A. \& Ilkevich, K.B. (2019a). Educational Environment Ecology as Factor of University Teacher Health Saving in Context of Education and Science Reforms in Modern Russia. Ekoloji, 107, 4937-4941.

Bayanova, A.R., Sivova, I.V., Kamasheva, Y.L., Popova, O.V., Semyanov, E.V., Shagieva, R.V., Yusupov, I.M. (2020). Student online services consumption: Routine practices or mistrust to digital service? Contemporary Educational Technology, 11(1), 47-54.

Bayanova, A.R., Sizova, Z.M., Chistyakov, A.A., Prokopyev, A.I. \& Vasbieva, D.G. (2019b). A philosophical view of organizational culture policy in contemporary universities. European Journal of Science and Theology, 15(3), 121-131.

Becker, R. \& Kolster, R. (2012). International student recruitment: policies and developments in selected countries. Hague: NUFFIC.

Bubnova, I.S., Khvatova, M.A., Chernik, V.E., Popova, O.V., Prokopyev, A.I., Naumov, P.Y. \& Babarykin, O.V. (2018). Research of Professional Activity Features of Ecologist at Carrying Out Public Ecological Examination. Ekoloji, 106, 999-1006.

Caliskan, S., Guney, Z., Sakhieva, R.G., Vasbieva, D.G., \& Zaitseva, N.A. (2019). Teachers' Views on the Availability of Web 2.0 Tools in Education. International journal of emerging technologies in learning, 14(22), 70-81.

Cherdymova, E.I., Vorobyeva, K.I., Romashkova, O.V., Mashkin, N.A., Grigoriev, S.M., Romanchenko, L.N., Karpenko, M.A. \& Bayanova, A.R. (2018). Photo Exhibition Influence on Student Environmental Consciousness Formation. Ekoloji, 27(106), 1271-1278.

Concept of promoting Russian education on the basis of Russian Collaboration representative offices abroad. (2014). URL: http://rs.gov.ru/sites/default/files/koncepciya_prodvizheniya_rossiyskogo_obrazovaniya_v_razdel_ekport_ro.pdf

Concept of the state migration policy of the Russian Federation for the period up to 2025. (2012). URL: http://www.fms.gov.ru/documentation/868/details/53252/ 
Concept of the state policy of the Russian Federation in the field of training national personnel for foreign countries in Russian educational institutions. (2016). URL: http://www.russia.edu.ru/information/legal/law/inter/conception/.

Domorovskaya, O.G. (2007). Socio-pedagogical conditions of adaptation of migrant students in the cultural and educational space of the University: Abstract of $\mathrm{PhD}$ in pedagogical Sciences. Rostov-on-Don. 23.

Drozhzhina, D.S. (2013). Studying the adaptation of International students: a discussion on methodology. Empirical study. Universitas, 1(3): 33-47.

Ezhov, K.S., Cherdymova, E.I., Prokopyev, A.I., Fabrikov, M.S., Dorokhov, N.I., Serebrennikova, Y.V., Belousov, A.L. \& Efimova, O.S. (2019). Conflict features depending on stay duration at workplace. Dilemas contemporáneos: Educación, Política y Valores, 4 (Special Edition), Article No: 38.

Faleeva, L.V., Bratukhina, E.V., Ezhov, S.G., Gorbunova, L.N., Lopanova, A.P., Viaznikova, L.F., \& Kryukova, N.I. (2017). Student's Social Experience Forming in University Vocational Training. Eurasian Journal of Analytical Chemistry, 12(7B), 1127-1135.

Gafurov, I.R., Ibragimov, G.I., Kalimullin, A.M. \& Alishev, T.B. (2020). Transformation of education in higher education. Higher education in Russia, 10, 101-112. Moscow.

Gladush, A.G., Trofimova, T.N. \& Filippov, V.M. (2008). Socio-cultural adaptation of foreign citizens to the conditions of study and residence in Russia. Moscow: People's friendship University.

Ivanova, M.I. (2001). Socio-psychological adaptation of international students to higher education in Russia: Doctoral Dissertation. St. Petersburg.

Kargapoltseva, N.A., Rakhimova, O.N., Shabalina, L.G., Guryanova, T.Y., Mashkin, N.A., Mirzalimov, R.M. \& Popova, N.F. (2019). Student Identity and Various Procedures of its Development. International Journal of Applied Exercise Physiology, 2, 519-526.

Krivtsova, I.O. (2011). Socio-cultural adaptation of international students to the educational environment of a Russian University. Fundamental study, 8(1), $284-288$.

Kutuev, R.A., Mashkin, N.A., Yevgrafova, O.G., Morozov, A.V., Zakharova, A.N. \& Parkhaev, V.T. (2017). Methodological Guidance of Educational Monitoring Effectiveness. Modern Journal of Language Teaching Methods, 7(3), 405-41.

Kvon, G.M., Vaks, V.B., Kalimullin, A.M., Bayanova, A.R., Shaidullina, A.R., Dolzhikova, A.V. \& Lapidus, N.I. (2019). Developing the Informational and Digital Environment of a University: Problem Analysis and Assessment. Eurasia Journal of Mathematics, Science and Technology Education, 15(10), em1767. URL: https://kpfu.ru/staff_files/F1126799205/Developing_the.pdf

Lessons of the Stress test: universities in the context of the pandemic and after it. (2020). Analytical report. Access mode: https://www. hse.ru/data/2020/07/06/1595281277/003_\%D0\%94\%D0\%BE\%D0\%BA\%D0\%BB\%D0\% B0\%D0\%B4.pdf.

Malikov, A.V., Potapova, I.I. \& Gavrilyuk, E.S. (2020). Adapting University faculty to the challenges of the digital economy. Creative economy, 14(6), 1011-1020.

Marinoni, J. \& Hilligye van't, L. (2020). The impact of COVID-19 on global higher education. International Higher Education, 102, 8-9. Moscow.

Mironova, M.D., Zaitseva, N.A., Larionova, A.A., Akhpolova, V.B., Glagoleva, L.E., Belozerova, J.M. (2017). Features of Innovative Personnel Management of Service Companies in the Period of Implementation of Organizational Changes. Eurasian journal of analytical chemistry. 12(5B), 793-802.

Natolochnaya, O.V., Kryukova, N.I., \& Buslaev, S.I. (2016). The development of the public education system in the Caucasus in the pre-revolutionary period (1905-1917 years). Bylye Gody, 39(1), 222-228.

Orekhovskaya, N.A., Chistyakov, A.A., Kryukova, N.I., Krokhina, J.A., Ospennikov, Y.V., \& Makarova, E.V. (2019). Orthodoxy and Modernity their Contact Facets in Russian Society. European Journal of Science and Theology, 15(2), 67-77.

Pushkarev, V.V., Cherdymova, E.I., Prokopyev, A.I., Kochurov, M.G., Shamanin, N.V., Ezhov, S.G., Kamenskaya, S.V. \& Kargina, N.V. (2019). Motivation and needs in the area of the 
spouses with different experiences of cohabitation. Dilemas contemporáneos: Educación, Política y Valores, 4 (Special Edition), Article No: 41.

Razumovskaya, M.I., Larionova, A.A., Zaitseva, N.A., Orekhov, V.D., Trufanova, S.N., Korzhanova, A.A., \& Takhumova, O. (2018). Modeling the network integration space for educational programs. Modern journal of language teaching methods, 8(5), 56-67.

Report on international migration of the UN population Division. (2012). http://www.un.org/esa/population/meetings/tenthcoord2012/WorldMigrationReport2009.p df.

Rudenko, L.G., Larionova, A.A., Zaitseva, N.A., Kostryukova, O.N., Bykasova, E.V., Garifullina, R.Z., Safin, F.M. (2018). Conceptual model of training personnel for small business services in the digital economy. Modern journal of language teaching methods, 8(5), 283-296.

Salnikova, E.A. (2020). Attracting international students to higher education institutions in Germany and Russia. Questions of student science, 3(43), 148-156.

Shtykhno, D.A., Konstantinova, L.V. \& Gagiev, N.N. (2020). Transition of universities to remote mode during the pandemic: problems and possible risks. Open education, 24(5), 72-79.

The 100 Most International Universities in the world. (2015/2018). Times Higher Education World University Rankings URL: https://www.timeshighereducation.co.uk/news/the-100-mostinternational-universities-in-the-world-2015/2018125.article?nopaging=1

Valers, M. (2018). Internationalization of universities: the German way. International higher education. Issue $92 . \quad$ URL: https://www.bc.edu/content/dam/bc1/schools/lsoe/sites/cihe/WHE_19_view.pdf

Vashurina, E.V., Vershinina, O.A. \& Gazieva, Ch.F. (2016). Attracting foreign students to Russian universities. Yekaterinburg: publishing house of the Ural University. 